\title{
Características posmodernas en Boquitas pintadas, de Manuel Puig
}

Postmodern Characteristics in Manuel Puig's Boquitas pintadas

Giancarla Di Laura ${ }^{1}$

Prairie View A \& M University, Texas, Estados Unidos

giancarladilaura@att.net

\section{RESUMEN}

La mayoría de su obra literaria, novelística, dramática y sus guiones cinematográficos se caracterizan por incluir textos literarios y no literarios. Muchos de estos discursos son manifestaciones culturales, como las canciones, la fotonovela, la telenovela y las películas. Manuel Puig y su obra ocupan un sitio muy importante en las letras latinoamericanas. Boquitas pintadas (1969) es una novela que trata la vida de los habitantes de un pueblo, Coronel Vallejos, quienes asumen una realidad totalmente diferente a la anhelada. Las acciones que ellos ejecutan sirven para cumplir con un imaginario social preestablecido. Las letras de las canciones, que en su mayoría pertenecen a tangos, prefiguran el acontecer de cada historia. Boquitas pintadas revitaliza la forma de folletín, es decir, las historias amorosas, pero esta vez, en lugar de tener un final feliz, nos deja cuestionando la vida en sí. Este cuestionamiento surge por parte de la actitud del narrador, quien utiliza un lenguaje con una gran carga irónica. Las características posmodernas en esta novela tienen un efecto bastante interesante, ya que, a través de ellas, se puede llevar a la pantalla grande del sétimo arte. La heterogeneidad de discursos facilitan las actuaciones para hacerla una película.

1 Giancarla Di Laura, Ph.D. Estudió el bachillerato y la maestría en Literatura Hispánica en Wichita State University, Wichita, Kansas. Luego se doctoró de la Universidad de Arizona, en Tucson, en 2004. Su disertación se tituló La ironía en la novelística de Julio Ramón Ribeyro. Ha expuesto numerosos trabajos literarios en conferencias nacionales e internacionales sobre Julio Ramón Ribeyro y la Generación del 50. Asimismo, ha presentado y publicado artículos sobre poesía peruana. En la actualidad es profesora de Español y Literatura en Prairie View A \& M University (Houston, Texas), donde enseña y vive. 


\section{PALABRAS CLAVE}

Pastiche cultural, posmodernidad, ironía, escepticismo, narrativa del Boom, heterogeneidad discursiva

\section{ABSTRACT}

Most of Manuel Puig literary work is well known because of the usage of different discourses literary and non-literary. Many of these documents belong to different cultural areas, names of songs, obituaries, magazine, newspapers, movies, and so on. Boquitas pintadas (1969) is his second novel that is developed in a fictitious town, called Coronel Vallejos. Most of the characters live their lives according to the social imaginary, without trying to be authentic. Irony is used as a narrative strategy where skepticism is the result of questioning life styles. Also, many postmodern characteristics are used in the configuration of the text. Boquitas Pintadas has many visual types of scenery which made it easier to turn it onto a movie, released on 1974.

\section{KEYWORDS}

Cultural pastiche, post modernity, irony, skepticism, Boom Narrative, heterogeneity discourses

Dotado por una talentosa carrera literaria, Manuel Puig (1932-1990) nació en General Villegas, Argentina, y vivió en su ciudad natal, Buenos Aires, Roma, Londres, Nueva York, Río de Janeiro y Cuernavaca.

Desde sus inicios proyectó una gran influencia del cine en sus obras. Caracterizada su literatura por fusionar diversos tipos de textos y crear así un «pastiche» de expresiones culturales, su novelística se construye sobre la base de manifestaciones literarias y no literarias, es decir, de documentos formales e informales y de géneros considerados «menores», como el folletín ${ }^{2}$, el radioteatro sentimental o la telenovela, unidos a relatos e historias narradas en tercera persona. Escribió ocho novelas, adaptaciones escénicas y guiones cinematográficos; en su obra destacan La traición de Rita Hayworth (1968), Boquitas pintadas (1969), The Buenos Aires Affair (1973), El beso de la mujer araña (1976), Pubis angelical (1979), Maldición eterna a quien lea estas páginas (1980), Sangre de amor correspondido

2 El folletín nace a fines del siglo XVIII con el fin de mantener y aumentar suscriptores. Deja la función puramente noticiosa y crítica e incluye lo ficticio. La función del folletín no es proporcionar conocimiento ni provocar goce estético; a lo que apunta es a ofrecer el reflejo de anhelos insatisfechos, alineándolos de la realidad. 
(1982) y Cae la noche tropical (1988), en cuanto a prosa; Bajo un manto de estrellas (1983), drama; y finalmente sus guiones, La cara del villano y Recuerdo de Tijuana (1985).

Muchas de sus novelas conllevan menciones de películas y canciones, que ocupan un papel fundamental en la construcción de su discurso narrativo, y también son presagio y encabezamiento de la obra en sí. En todas sus novelas, el autor implícito a través de una actitud irónica cuestiona parámetros establecidos por una sociedad moldeada por artistas hollywoodenses y estereotipos populares que proyectan una falsa realidad de la vida.

La segunda novela publicada por Manuel Puig, Boquitas pintadas (1969), cuyo propósito era fusionar las diferentes expresiones artísticas para crear un collage de diversos discursos pertenecientes a medios populares, es el libro que tuvo una excelente crítica en el momento de su publicación. Compuesta por 16 capítulos, divididos en dos partes: «Boquitas pintadas de rojo carmesí» y «Boquitas azules, violáceas, negras», tienen como significado los subtítulos de la novela a los sentimientos que se manifiestan en las diversas etapas de la vida y que corresponden a dos momentos específicos de la vida del personaje principal. En la primera parte se puede distinguir la pasión, el amor, la juventud de Juan Carlos Etchepare, y en la segunda, las tonalidades sugieren un desánimo y pesimismo en cuanto a la vida del protagonista. Esta novela está construida sobre la base de cartas, narraciones, diálogos directos, diarios íntimos, álbumes de foto, agendas, expedientes y publicaciones, donde lo individual y lo popular se confabulan para descentralizar el poder del texto, y si bien la autoría pertenece a una voz conocedora y responsable del relato, la narración se fragmenta por medio de inserciones de textos no literarios. Boquitas pintadas fue llevada a la pantalla de cine en 1974. La dirección perteneció a Leopoldo Torre Nilsson.

Manuel Puig pertenece a la generación del Boom, que ocupó un auge espectacular en la década de 1960. Con su primera novela, La traición de Rita Hayworth, publicada en 1968, Puig alcanzó cierta popularidad, pero con la publicación de su segunda novela ganó un lugar primordial en la narrativa latinoamericana.

Boquitas pintadas es un libro que desde su propio título crea un diálogo con discursos populares, como los tangos del famoso Carlos Gardel. Los versos del tango rezan: «Deliciosas criaturas perfumadas, quiero el beso de sus boquitas pintadas» ${ }^{3}$. El perfume y el color labial atienden a

3 Esta información es sacada del título de una entrevista que le hicieron a Manuel Puig en Buenos Aires, Argentina, en 1972. 
una necesidad de embellecimiento y provocación. Asimismo, esta novela se caracteriza por tratar los comportamientos mediatizados por una sociedad marginal que busca aparentar modelos diseñados por un imaginario tradicional que quisieran alcanzar. Es decir, la acción de esta novela transcurre entre 1935 y 1960, y los personajes proyectan vivir en un mundo gardeliano donde hay una gran libertad; sin embargo, siguen comportamientos tradicionales y retrógrados.

Coronel Vallejos es un pueblo ficticio de la provincia de Buenos Aires, donde Puig sitúa sus dos primeros relatos ${ }^{4}$. Muchas veces se ha mencionado que la narrativa de Puig se identifica con la literatura de folletín y con el melodrama, conocidas formas populares donde lo cursi y lo poco convencional suceden y tienen éxito. Irónicamente, en las novelas de Puig, no encontramos que la felicidad ocurra o que el final sea de Hollywood; al contrario, los textos de este escritor proyectan una realidad auténtica y muchas veces cruda, y hacen una crítica puntual y aguda a la sociedad latinoamericana, específicamente la argentina. En estas novelas siempre se habla de lo prohibido, a través del ocultamiento, la simulación, la hipocresía y la envidia que existe en un lugar claustrofóbico y sofocante donde el daño y la maldad están presentes.

Cada episodio está precedido por versos de canciones populares, en su mayoría de letras de tango ${ }^{5}$. La inclusión de versos de tangos de figuras populares como los artistas Alfredo Le Pera y Luis Rubinstein encaminan cada relato y revelan una nueva significación.

PRIMERA ENTREGA

Era... para mí la vida entera...

Alfredo Le Pera

NOTA APARECIDA EN EL NÚMERO CORRESPONDIENTE ABRIL DE 1947 DE LA REVISTA MENSUAL NUESTRA VECINDAD, PUBLICADA EN LA LOCALIDAD DE CORONEL VALLEJOS, PROVINCIA DE BUENOS AIRES «Fallecimiento lamentado. La desaparición del señor Juan Carlos Etchepare, acaecida el 18 de abril último, a la temprana edad de veintinueve años, tras soportar las alternativas de una larga enfermedad, ha producido en esta población, de la que el extinto era querido hijo, general sentimiento de apesadumbre sorpresa, no obstante conocer muchos allegados la seria afección que padecía» (Puig, 2004, p. 9).

4 La primera vez que desarrolla Puig su texto novelístico es con la novela La traición de Rita Hayworth (1968).

5 El tango es una forma popular de segunda mitad del siglo XX, cuya letra expresa los problemas cotidianos y el sentimiento de la gente humilde. Tuvo una rápida difusión debido a sus temas accesibles y al uso de un lenguaje coloquial que registraba hechos cotidianos. 
Por lo general, toda la obra de Puig trata de romper las barreras de géneros literarios y los no literarios. Esta novela irrumpe con la nota necrológica del personaje principal, Juan Carlos Echepare, el donjuán del mencionado pueblo, cuya muerte natural por contagiarse con tuberculosis lo mata a una joven edad. En esta novela, empezamos con la muerte del protagonista, así que a través del relato encontramos una narración que describe las acciones vividas en un pasado remoto.

La posmodernidad sugiere la idea de representar una dialógica discursiva cultural, que proyecte desde diferentes campos la construcción de algún objeto textual; en este caso, las manifestaciones artísticas se agrupan y se ocupan de dar un nuevo sentido a una obra que por sí sola tiene un significado diverso. Al combinar textos de diferentes orígenes, como defunciones, actas policiales, cartas personales o recortes de revista, con discursos directos, como diálogos y libre asociación de ideas y narraciones del relato, se recuerda el discurso cinematográfico, donde diferentes episodios configuran el texto o la película. Imágenes visuales son reproducidas mediante los relatos de Puig y entablan una relación íntima con el sétimo arte.

La sexta entrega se configura por medio de diferentes discursos narrativos: una lectura de cartas llevada a cabo en un Campo Provisional, una secuencia de acciones de la romería popular, una carta del doctor Juan José Malbrán al doctor Mario Eugenio Bonifaci advirtiendo sobre condición médica del paciente Etchepare:

La Sota de Espadas pelada, ¿alguna perra se me murió pelada? La perra quemada tenía pelo, la carboncito, la cenicita, la Pelada o es una Mentira de pichona preñada que no está preñada, o es una Venganza, de alguna pichona mala (Puig, 2004, p. 95).

ROMERÍAS POPULARES EFECTUADAS EL DOMINGO 26 DE ABRIL DE 1937 EN EL PRADO GALLEGO, SU DESARROLLO Y DERIVACIONES

Hora de apertura: 18:30 horas

Precio de entradas; caballeros un peso, damas veinte centavos [...] (Puig, 2004, p. 95)

Dr. Juan José Malbrán

Coronel Vallejos, Pcía. de Bs. As.

23 de agosto de 1937

Dr. Mario Eugenio Bonifaci

Hostal Médico «San Roque»

Cosquín, Pcía. de Córdoba

Respetado colega:

Ante todo le pido disculpas por mi demora en contestarle, debida créame al deseo de informarme mejor sobre el caso Etchepare. Debo 
confesarle que no comprendo la reacción del muchacho, yo lo conozco desde que nació y lo consideraba de carácter fuerte, empecinado sí, pero siempre de provecho. No sé por qué no obedece al tratamiento (Puig, 2004, p. 101).

Cada texto expresa un tipo diverso de vínculo sobre la historia relatada, cada relato llena un vacío que tiene como totalidad llenar un mosaico por medio de un lector capacitado y activo. De esta manera, cada acción desarrollada corresponde a una imagen visual y descriptiva de algún espacio particular; influenciado por el cine, Puig trata de usar un lente cambiante que se enfoque en diferentes secciones al mismo tiempo. Esta simultaneidad de discursos sobre los personajes, donde una voz narrativa relata lo que sucede, al mismo tiempo no descentraliza el poder ni la omnisciencia del narrador, pero a la larga los discursos puestos en conjunto sugieren una nueva forma de lectura y exigen la participación de un lector ávido y activo. El receptor del relato debe concentrar toda su atención en la lectura para llenar espacios en blanco y establecer las relaciones de causa y efecto, así como descubrir la ideología encerrada en el texto. El montaje de escenas, tiempos, sucesos simultáneos y tratamiento fragmentado y discontinuo son los más grandes aportes del cine a la literatura. Además, la gran contribución que ha hecho la producción cinematográfica consiste en evadir la realidad.

La ironía es una estrategia narrativa para Puig, en el sentido que la utiliza con un fin humorístico pero también cuestionador. Es decir, la desobjetivación del mundo narrativo cuya despersonalización del narrador corresponde a su incapacidad para interpretar la realidad o por el abandono de su aptitud para hacerlo. Es decir, mediante la aparición de diferentes textos se despersonaliza y desintegra el narrador y se cuestiona la autoría narrativa. El escepticismo surge a partir del cuestionamiento sobre los motivos de la caída en cuanto a decadencia y caos que proyecta la sociedad.

Los personajes, que representan una gama entera de estereotipos culturales y tradicionales en los textos literarios y no literarios de la historia, son cómplices de las aventuras, las traiciones y los abusos, y el lector se comprende la necesidad de una ruptura con parámetros sociales establecidos.

Los personajes femeninos principales son tres mujeres que aparentan ser de una manera, pero viven de una forma muy diferente. Es decir, ninguna de ellas vive su realidad, no son auténticas, modelan estereotipos aceptados por una sociedad tradicional: Nené, quien mantiene una relación liberal con Juan Carlos; Mabel, la pudiente, la novia formal de Juan Carlos, quien está con ella porque ocupa un lugar alto en la escala social; y la viuda Di Carlo, con la que mantiene una relación física. 
El gran aporte que produce la narrativa de Manuel Puig es crear un texto polifónico en cuanto a discurso, aunque todavía se ve que la mayoría de personajes proyectan una sola visión de mundo, no hay un contrapunto de voces. Sin embargo, su aporte vital recae en la inclusión de los diversos géneros para crear un texto literario totalitario, nutrido por diversas voces.

Si la posmodernidad tiene ciertas características que se encaminan a una descentralización de poder y a la inclusión de diversos discursos que establezcan un diálogo abierto a otros textos, definitivamente Puig es uno de los primeros en abrir una nueva era en cuanto a la narrativa latinoamericana se refiere. 


\section{REFERENCIAS BIBLIOGRÁFICAS}

Puig, M. (2004). Boquitas pintadas. Barcelona: Editorial Seix Barral.

Recibido: mayo de 2015

Aceptado: julio de 2015 